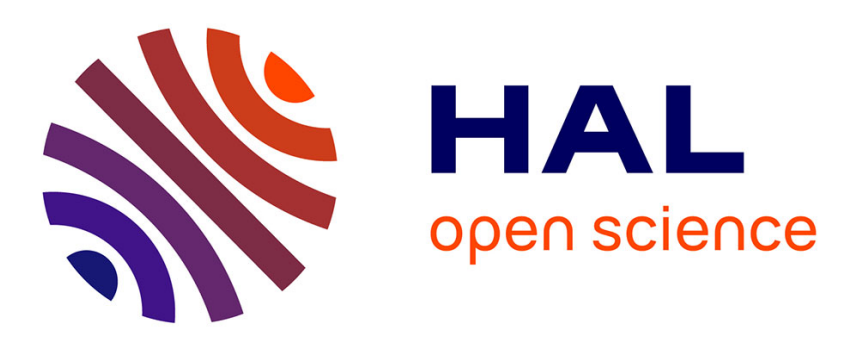

\title{
Using connectives in oral French narratives: Cognitive constraints and development of narrative skills
}

\author{
Monique Vion, Annie Colas
}

\section{To cite this version:}

Monique Vion, Annie Colas. Using connectives in oral French narratives: Cognitive constraints and development of narrative skills. First Language, 2005, 25 (1), pp.39-66. hal-00134182

\section{HAL Id: hal-00134182 \\ https://hal.science/hal-00134182}

Submitted on 1 Mar 2007

HAL is a multi-disciplinary open access archive for the deposit and dissemination of scientific research documents, whether they are published or not. The documents may come from teaching and research institutions in France or abroad, or from public or private research centers.
L'archive ouverte pluridisciplinaire HAL, est destinée au dépôt et à la diffusion de documents scientifiques de niveau recherche, publiés ou non, émanant des établissements d'enseignement et de recherche français ou étrangers, des laboratoires publics ou privés. 


\title{
Using connectives in oral French narratives: Cognitive constraints and development of narrative skills
}

\author{
Monique $\mathrm{VION}^{1}$ \& Annie COLAS \\ Laboratoire Parole et Langage, UMR 6057 CNRS-Université de Provence
}

\begin{abstract}
This study deals with the use of connectives in oral French narration. Seven- to eleven-year-old native speakers of French told 'silent' comic strip stories involving two characters to a same-age peer. The comic strips differed from each other in the display mode (consecutive vs. simultaneous), the type of event sequence (arbitrary vs. ordered) and the thematic continuity (continuous vs. discontinuous). The analysis concerns the part of the children's narrations where the same character carried out a sequence of actions. The results showed that: (1) more connectives were used when the speaker could see all the pictures at once; (2) regardless of the type of sequence, connectives that marked a temporal link outnumbered all others; and (3) thematic continuity promoted temporal-link marking by 7-year-olds and causal-link marking by 11-year-olds. The discussion addresses the conceptual determinants of the use of connectives, particularly temporal markers, and the developmental findings obtained by manipulating the conditions of production.
\end{abstract}

\section{KEYWORDS:}

Acquisition of French; cognitive constraints; communicative competence; connectives; discourse planning; oral narration; picture stories; textual cohesion

To tell a story, a speaker must encode the story's content in a culturally predefined discourse format. Typically, narrations are about an agent carrying out a series of actions involving animate or inanimate objects. More specifically, narrating is a sentence-generating process that abides by certain regularities. A narrative sequence is a relatively autonomous entity, endowed with an internal network-like structure of hierarchical relationships that interconnect a setting (or orientation), a conflict (or complication), a series

\footnotetext{
${ }^{1}$ Address for correspondance

Dr Monique Vion, Université de Provence, CNRS, UMR 6057 Parole et Langage, 29 Avenue Robert Schuman, F13621 Aix-en-Provence Cedex 1, France. E: mvion@up.univ-mrs.fr
} 
of actions or an evaluation, a resolution (denouement), an ending, and sometimes a final evaluation. Putting a story into narrative format requires the use of a number of linguistic devices (for an inventory, see, for example, Hemphill, Picardi, \& Tager-Flusberg, 1991; Peterson \& McCabe, 1983). Certain devices are formal and specific to narration (opening and closing devices) while others - such as connecting devices expressing semantic relations (e.g., temporal, additive, adversative and causal relations) which ensure the progression of the narration process - are used to structure any kind of discourse. Narrative skills concerning both devices are known to develop significantly during the elementary school years (Botvin \& Sutton-Smith, 1977).

The present study focuses on how and when children use connectives. These are text organizers whose function is to signify a relationship between uttered propositions (Bronckart, 1996; Fayol, 1997; Schiffrin, 1987; Segal, Duchan, \& Scott, 1991). A proposition is a predication (the attribution of properties to an entity, which constitutes the referential aspect of the proposition) in which the speaker becomes engaged (speaker involvement or enunciative aspect) and which is linked to other propositions (textual aspect). Links between propositions are achieved at two levels: by connectivity (propositions succeed each other linearly) and hierarchy (propositions are organized into a hierarchical structure) (Adam, 1992). As the observable trace of the process of establishing conceptual relationships, connectives are cues that provide access to the meaning of discourse relations.

Authors have different views concerning the role of connectives. For some, a relation expressed by a connective (i.e., a marked relation) is an equivalent variant of a relation expressed without a connective (unmarked). This is the case, for example, in 'I get up, I wash, I get dressed', where a simple juxtaposition is sufficient for both the speaker and the listener, unless stated otherwise, to consider that the events occur in succession. For other authors, marked and unmarked relations are not equivalent (for a detailed presentation of the various viewpoints, see Rossari, 2000; Segal et al., 1991). As noted by McCabe \& Peterson (1991), in comparison with other types of text, narratives have a very high densitiy of these markers of discourse cohesion, even if, for example, it is unnecessary for inter-propositional temporal links to be present for the narrative to be understood.

The study deals with the oral narration of a series of pictures. The pictorial medium has been an important means of observation in research on narrative development (Bamberg, 1987, 1997; Berman \& Katzenberg, 1998; Berman \& Slobin, 1994; Clancy, 1979; De Weck, 1991; Fine, 1985; Jisa, 2000; Jisa \& Kern, 1998; Kern, 1998; Norris \& Bruning, 1988; Roth \& Spekman, 1989). Picture-based tasks are known to be more demanding for the speaker than tasks where spontaneous or prompted productions are collected (Peterson, 1993; Roth, Spekman, \& Fye, 1995). The reason generally given is that the former require speakers to intentionally mobilize skills which are often still situation-specific. For example, a child may very well understand a given type of relationship in his/her own activities (such as causality), without understanding it for pictured characters in events presented by an experimenter. 
Although verbalizing pictorial narratives requires the processing of pictures, the cognitive processes it involves have not been studied in detail and are still poorly understood (Deutsch, 1975; McGann \& Schwartz, 1988; Schwartz, 1995). Some authors have stressed the importance of inference-making in this task (see overviews by Stein \& Albro, 1997; Trabasso \& Stein, 1997). The speaker must not only understand the events represented in each picture, but also how they are connected to each other. This requires inferring the meaning of each picture, and building a representation of the story as a whole by establishing temporal and causal links between the depicted events. The processes required for this task are known to be acquired gradually (van den Broek, Bauer \& Bourg, 1997). Preschool children (until about age 6) tend to focus on characters and actions; they recognize causal relations between physical events and actions but have trouble when the actions involve a character's goals or motivations. It is not until later that children exhibit greater sensitivity to the role of goals and motivations in the accomplishment of events; their grasp of causal relations solidifies gradually between ages 7 and 10-11 (van den Broek, 1997).

Other authors have noted the importance of the way the depicted events are presented for narrative purposes (Canoz \& Vion, 1994; Danset-Léger, 1978). Various cases are possible. In some situations, the child can view the pictures before beginning the narration. In this case, the pictures may remain visible throughout the narration or be rediscovered one by one as the child tells the story. In other situations, the speaker sees only one picture at a time and has to make the connection between the current content and the previous content as the story is being told. In this case, the storyteller is not allowed to look ahead or backtrack, so verifications aimed at understanding the temporal and causal structure of the events are rendered impossible.

The present experiment is part of a larger research project designed to study the cognitive constraints (memory-based and/or inferential) that affect the establishment and management of links between events (Vion \& Colas, 1998, 1999a, 1999b). The general hypothesis is that the linguistic expressions which structure discourse are the manifestation of conceptual constraints imposed by the information management process (Bronckart, 1985; Chafe, 1986). The aim of the experiment was to show that connective use in narratives is not only dependent upon the child's narrative skills, as numerous studies have shown (for reviews, see Favart, 1997; Fayol, 1997). It was hypothesized that connective use is also dependent upon the pictorial medium, particularly upon how explicitly the pictures depict the links between the events to be related and the span of the pictorial content available for production planning. In other words, it was hypothesized that the pictorial medium should be more or less conducive to the linguistic marking of inter-propositional links as a function of these variables. By varying the conditions of information availability (simultaneous vs. gradual), inference making (ordered vs. arbitrary nature of the event sequences) and thematic continuity (continuous vs. discontinuous) in the pictorial narratives proposed here, we provided verbalizing conditions that were more or less favourable to establishing 
conceptual relationships. Manipulating the frame display mode allowed us to control whether speakers could (simultaneous display) or could not (consecutive display) engage upon verifications that might help them create or understand the temporal and causal structure of the events to be related. Manipulating the type of event sequence provided a way of varying the amount of information available for ascertaining a thematic unit, establishing links between the depicted events and assigning thoughts, plans or affective reactions to the characters in order to make a story. Manipulating thematic continuity was a way to assess the effects of anticipation on the expression of inter-event links. Predictions concerning the explicit marking of inter-propositional links in each case will be detailed in the next section.

Native French-speaking children (aged seven to eleven) were asked to tell stories depicted in comic strips with no text. The obligation underlying this request was that the comic strips had to depict a story, and that the story had to be 'tellable' (Hausendorf, 1993; Hausendorf \& Quasthoff, 1992).

\section{METHOD}

\section{Participants}

A total of 191 native French-speaking children (boys and girls from middle-class families) aged 7-11 years participated in the study. The children were randomly choosen from elementary schools in Aix-enProvence, France. They evidenced no form of language or learning disorder. There were 63 7-year-olds (attending first grade, median age: 6;6), 64 9-year-olds (attending third grade, median age: 8;8) and 64 11year-olds (attending fifth grade, median age: 10;6).

\section{Materials}

The comic strips contained eight $8 \_8 \mathrm{~cm}$ frames (F1-F8). The first frame showed two characters. All subsequent frames showed only one of the two characters carrying out various activities. A minimal link between the frames was achieved by the continuous presence of one of the characters throughout the story. The comic strips differed as to whether the event sequence was arbitrary or ordered (Fig. 1 presents the type of events sequence). In the arbitrary sequences, the events in each comic strip, although presented as a sequence, could occur in any order. For example, the activities depicted in Fig. 1a are relatively independent of each other, and thus required inference making: the woman getting dressed (or undressed) could have been placed after the women putting on (or taking off) her makeup, or anywhere else in the sequence for that matter. In this case, the speaker had to infer the links between the pictures from the proposed sequence in order to build an overall representation of the story. In the ordered sequences, the order of the events could not be changed. For example, in Fig. 1b, before potentially catching a fish, the man had to put on his fishing gear, go to the water's edge and cast the line. Note, however, that although the events 
were proposed in a chronological order that was more constrained than in the arbitrary condition, the ordered stories still did not have a script structure because the normal sequence of events was modified by the sudden appearance of an obstacle. The obstacle was always an event over which the main character had little or no control. In some of the comic strips, the obstacle interrupted the causal chain of events (e.g., the car hit a hedgehog crossing the road). In others, the obstacle did not interrupt the causal chain but created a surprise effect that sometimes substantially changed the expected course of events (e.g., the air bubble, which the fish entered so that it could fly, burst) and sometimes did not (e.g., the cereal bowl fell and made a hat for the cat hanging on the tablecloth).
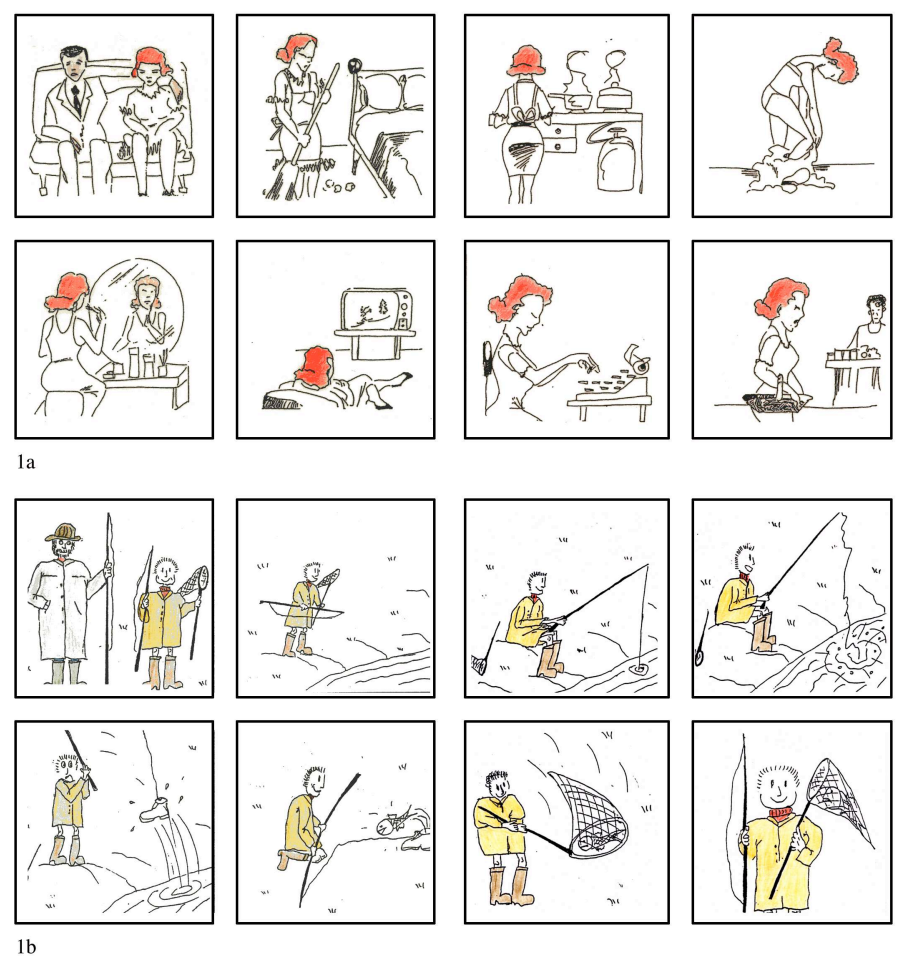

Figure 1 Type of sequence: (1a) arbitrary, (1b) ordered

In the simultaneous display mode, all pictures were on one page. The speaker was asked to look at the whole comic strip and prepare to tell the story immediately afterwards. In the consecutive display mode, the comic strip was presented in booklet format with one picture per page. Speakers were instructed to turn the pages one by one and to tell the story as they discovered each new picture.

Four different comic strip versions were constructed with the two characters (X and $\mathrm{Y}$ ) by taking all combinations of two variables, each with two levels. The first variable concerned the topic of the comic strip, which was either maintained or changed. In the maintained topic condition, the materials were 
designed in such a way that a thematic subject (Karmiloff-Smith, 1981) would be induced after the first frame by the repeated presence of the same character. This was achieved by having character $\mathrm{X}$ as the only character in every frame, up to and including the last one. In the changed topic condition, a thematic break was generated by having character Y reappear in the last picture. In other words, F2 through F7 showed X only, and F8 showed Y only. The thematic break was purposely introduced late so that the effects of anticipation on the expression of inter-event links could be assessed. The next variable was a secondary variable used to control the layout of the characters in the frames. To avoid any bias in referent marking brought about by the greater salience of one of the two characters due to its location in the picture, the layout (left, right) of the characters in the first frame was counterbalanced.

For each type of sequence, the materials consisted of 32 test comic strips ( 8 pairs of characters 4 versions) and 3 filler comic strips containing only one character. The fillers were interspersed with the test comic strips during the experimental phase (see list of materials in Appendix).

\section{Design}

Each speaker was tested in only one frame display mode and one type of sequence, but in both topic conditions. During testing, a given participant saw eight test comic strips (each presented in one of the four versions) and three filler comic strips (interspersed between two test comic strips).

\section{Procedure}

Testing was individual and lasted approximately 20 minutes. There were three people in the room where the experiment took place: the speaker, the experimenter and the addressee of the narration (the listener). The listener, a same-age peer from the speaker's grade in school, was seated too far away from the speaker to see the pictures and acted as the listener only once during the experiment.

In the simultaneous display where the entire comic strip was presented on a single page, the speaker was given the following instructions: 'I'm going to show you some comic strip stories. You'll see that there are no balloons in them, just pictures. You're going to have to tell the stories to your classmate, who can't see them. Be careful to talk about every picture, without forgetting any, and to tell them in the following order (the experimenter pointed to the pictures in the normal reading order). You may look at the pictures as long as you want before beginning.' First, a practice comic strip was shown to the child, who studied it and kept it in sight until s/he had finished telling the story. Then it was taken away and the remaining comic strips were offered one by one.

In the consecutive display where the comic strips were presented in booklets, the above instructions were modified as follows: 'I'm going to present some stories in booklets [the experimenter shows a booklet] ... Be careful to talk about every picture, without forgetting any. Talk about each picture, one after the other, and don't go back over them.' Then a practice story was presented. In this display mode, 
the experimenter reminded the speaker between each comic strip that $\mathrm{s} / \mathrm{he}$ had to work picture by picture without backtracking.

The instructions given to the listeners were the same in the two conditions: they were to listen carefully to the stories in order to understand them, but they were instructed not to talk.

\section{Preparing the data}

\section{Transcribing the recordings}

In all, 1528 narrations were tape-recorded: 760 productions from arbitrary comic strips $(95$ speakers -8 comic strips) and 768 productions from ordered comic strips (96 speakers - 8 comic strips). They were fully transcribed by the authors in accordance with the conventions established by Hickmann, Hendriks, Roland \& Liang (1994). Each text was then divided into three parts (F1, F2-F7, F8).

The transcription followed the rules stipulated in the CHILDES software (Child Data Exchange System; MacWhinney, 1991). The data were entered in the format defined by the system (CHAT module), which made it possible to search in the transcriptions for text strings or assigned codes (CLAN module).

\section{Segmenting and reducing the corpus}

The texts were broken down into 'utterances' on the basis of the following considerations. An 'utterance' was defined as: (1) any speech segment (sentence, clause, sentence fragment, phrase or word) whose final intonation contour was declarative (.), exclamatory (!) or interrogative (?); or (2) any syntactically and semantically independent proposition that contained a non-final intonation contour indicating continuation (...). Hesitations, hedges, repetitions, false starts, and comments were discarded.

\section{Detection of occurrences in the corpus}

As a first step, all forms likely to be employed as a syntactic connector or text organizer were tallied. These potential connectives could occur within the boundaries of an utterance (Examples 1, 2 and 3 below) or between two consecutive utterances (Example 4).

1. Un monsieur $\underline{\text { et }}$ son enfant font du vélo.

A man and his child are biking.

2. Il voit un pommier puis il prend une pomme.

He sees an apple tree then he takes an apple.

3. On dirait qu'il va se noyer parce qu'il gigote dans tous les sens.

It looks as if he'll drown because he's moving around in every direction.

4. Elle marche sur l'herbe après elle chante cocorico.

It walks on the grass after that it cries cock-a-doodle-doo. 
Whenever two or more of these connectives were combined, either with each other as in et puis (and then) or et puis après (and then after that), with a deictic as et là (in and there) or alors ici (so here), or with a temporal marker as in et pendant ce temps (and meanwhile) or mais alors (but then), the combination was taken as a unit, and its elements were connected with a plus sign in the transcribed text (e.g., and + so+then)

\section{Coding}

Each occurrence was assigned a three-part code. The first indicated the type of semantic link (temporal, additive, causal, adversative), the second was the form itself and the third was whether the form was used as a syntactic connector or text organizer.

Semantic value was established on the basis of the relationship between what the speaker said and the content of the pictures. Identifying the nature of the link denoted by a given form required an interpretation on the part of the coder. This interpretation was partly based on a substitution operation e.g., puis (then) was recognized as a marker of a temporal succession if it could be replaced by après (after that) or ensuite (next) - and on extra-textual cues, e.g., et (and) or puis (then) was interpreted as a marker of a temporal succession if it was employed to connect the narrations of two consecutive pictures. This method was derived from Bloom, Lahey, Hood, Lifter \& Fiess (1980) and consists of determining the meaning of the two elements being related to each other (phrases or propositions about objects, states or actions) on the basis of: (1) the meaning of the first element and the meaning of the second, (2) the fact that the two elements are linked by a connective, and (3) the fact that the speaker is talking about a given picture. The categories are listed with examples in Table 1. Note that the same form can be used to express various relationships ('and', for example, can be used as a temporal or as an additive marker). 
Table 1 Coding of semantic links

\begin{tabular}{|c|c|}
\hline Type of semantic link & Examples \\
\hline $\begin{array}{l}\text { ADDITIVE (CODE A): Two simultaneous or } \\
\text { consecutive elements objects, events or states, } \\
\text { often enumerations. Each element is semantically } \\
\text { independent, and the meaning is the same when } \\
\text { the two are combined or taken separately. }\end{array}$ & $\begin{array}{l}\text { Le papa prend sa douche et son parapluie } \\
\text { The dad takes his bag and his umbrella } \\
\text { il prend son parapluie puis sa valise } \\
\text { he takes his umbrella then his suitcase } \\
\text { il se réveille et il baille } \\
\text { he wakes up and he yawns } \\
\text { ''est un âne gris et un chat tout jaune } \\
\text { it's a grey donkey and an all yellow cat } \\
\text { il sort dehors puis il est tout content } \\
\text { it goes out then it's very happy } \\
\text { elle est dans la mer et elle voit un crocodile } \\
\text { he's in the sea and he sees a crocodile }\end{array}$ \\
\hline $\begin{array}{l}\text { SEQUENTIAL OR CHRONOLOGICAL (CODE } \\
\text { T): } \\
\text { Two elements related by temporal succession, i.e., } \\
\text { each new utterance refers to the next picture in the } \\
\text { series. }\end{array}$ & $\begin{array}{l}\text { c'est un papa qui se lève après i déjeune } \\
\text { it's a dad who gets up after that he has breakfast } \\
\text { elle ouvre le grillage et elle sort } \\
\text { she opens the gate and goes out } \\
\text { elle écoute la radio puis elle lave le linge } \\
\text { she listens to the radio then she washes the laundry }\end{array}$ \\
\hline $\begin{array}{l}\text { CAUSAL (CODE C): Relations of cause, } \\
\text { consequence, or effect. The cause is a sufficient } \\
\text { cause of the consequence. One proposition refers } \\
\text { to a planned or current action or state, and the } \\
\text { other gives a reason or a result. }\end{array}$ & $\begin{array}{l}\text { et sa femme lui a dit de réviser ce livre car ce livre est } \\
\text { très important pour son travail } \\
\text { and his wife tells him to review this book, since this } \\
\text { book is very important for his work }\end{array}$ \\
\hline $\begin{array}{l}\text { ADVERSATIVE (CODE M): A relation of } \\
\text { contrast between two events and/or states. The } \\
\text { expected outcome of what is described in the first } \\
\text { proposition is not what is described in the second } \\
\text { the relation between the propositions is opposition, } \\
\text { where one proposition refutes or opposes the other, } \\
\text { or one proposition qualifies or restricts the other. }\end{array}$ & $\begin{array}{l}\text { i décide d'appeler le petit chat mais } i \text { vient pas } \\
\text { he decides to call the little cat but it doesn't come }\end{array}$ \\
\hline
\end{tabular}

Determining whether a form was used as a syntactic connector or a text organizer was based on the following rules: forms located at the beginning of an utterance were labelled $b$ if used to connect the description of a picture to the preceding description; see après (after that) in Examples 5a and 5b. 
5a. Arbitrary sequence

F2: La fille elle fait le ménage

The girl does the housework

F3: après elle fait le déjeuner after that she makes lunch

F4: après elle s'habille ou elle se déshabille

after that she gets dressed or undressed

F5: après elle se maquille

after that she puts on her makeup

F6: après elle regarde la télé after that she watches TV

F7: après elle écrit un livre after that she writes a book

F8: et elle part au marché and she goes shopping.

5b. Ordered sequence

F2: après il respire after that it breathes

F3: il fait des petites bulles et une grosse it makes some little bubbles and a big one

F4: il rentre dans la grosse bulle it goes into the big bubble

F5: il sort de l'eau it comes out of the water

F6: recommence à aller dans l'air starts again to go up in the air

F7: la bulle elle éclate the bubble bursts

F8: et lui retourne dans l'eau and it goes back into the water.

Forms located within an utterance could either be within a clause or between two clauses. The best example for describing and illustrating the coding system is the connective 'and'. When 'and' was located 
within a clause, the items it connected could either be two subjects, in which case it was labelled $s$ (e.g., 'a little girl and a grandmother are playing chess'), two verbs, labelled $v$ ('he is going to drink and eat'), or two complements (objects), labelled $o$ (e.g. 'there's a crocodile and a turtle'). If it was between two clauses within an utterance and the clauses were independent, it was labelled $p$ ('a crocodile is looking out of the water and the tortoise is too small'). If it was between two clauses within an utterance and the clauses were coreferent, it was labelled py ('the tortoise was too small and it couldn't do it'). Cases of subject repetition were labelled $\operatorname{sr}$ ('she sits down and she listens to music').

The coding was done separately by each author using the rules described above. Disagreements in the codes assigned were scarce. The discrepencies between codes were resolved by discussion while strictly following these rules.

\section{Data base}

The analysis dealt with inter-propositional link marking during the narration of the events in frames F2-F7, where the same character carried out six actions in succession. The following cases were discarded from the analyses: (1) forms within segments of text where the narrator made the characters speak; (2) forms that coordinated phrases (e.g., 'and' in 'it makes some little bubbles and a big one'); (3) expressions that combined a connective and a deictic. Note that the expression 'and there' (et là) accounted for 78\% of the deictic expressions discarded from arbitrary sequence productions (it was mostly used at age 7 in simultaneous display) and $73 \%$ of the deictic expressions discarded from ordered sequence productions (where it was mostly found at ages 7 and 11 in consecutive display). The results presented below pertain to the remaining 2643 occurrences in arbitrary sequence productions and the remaining 2714 occurrences in ordered sequence productions.

\section{Predictions}

Explicit marking of links in a picture-based task requires grasping the fact that the series of separate pictures forms a whole. The ability to understand and mentally represent a series of events as an integrated whole is known to emerge and solidify gradually in the course of development (Bestgen, 1992; van den Broek, 1997). This means that progress should be noted in the expression of adversative and causal relations as children grow older.

Comic strips showing independent actions (arbitrary sequences) offered only a means of identifying a main character engaged in a series of actions. The only noticeable event in some of the comic strips was the return of character $\mathrm{Y}$ in the last frame (F8) after six frames (F2-F7) showing only character $\mathrm{X}$ (topic change). Managing to tell a story in this case required the speakers to infer the existence of a consecutive

link between each event and the next. Arbitrary sequences should lead speakers who are following the instructions (this is a story and it is tellable) to express the consecutiveness of the events by explicitly 
marking the temporal succession. The link markers that should be used to indicate this chronological order are the ones considered in French to express a loose relation between consecutive events, namely, puis (then), après (after that), and ensuite (next) (Bestgen, 1992; Bestgen \& Costermans, 1994; Favart, 1997; Fayol, 1986; Jisa, 1984/85; Mouchon, Fayol \& Gombert, 1991). The ordered sequences, on the other hand, also permitted the identification of a main character, but in addition they supplied further indications that made it easier to find a scenario and relate the events to each other. The presence of an obstacle, which, from the standpoint of the main character, broke the chain of events, should promote the staging of a story. Ordered sequences should thus lead speakers who are following the instructions not only to express the consecutiveness of the events, but also to infer specific links inherent in the unexpected nature of certain events, the occurrence of a complication or the beginning of a solution. The markers used here should be ones that express the appearance of a problem and its consequences (markers of adversative or causal relations; Fayol, 1986, 1997).

The frame display mode served to vary the constraints imposed on the organization and planning of story content (Bock, 1995; Levelt, 1989). Consecutive display reduced the amount of available information and, since looking forward or backward in the material was not allowed, only mental backtracking was possible. This mode should make it harder to understand that the picture sequence forms a whole and should therefore be more likely to lead the youngest speakers to describe the events as an unrelated series or to produce few linkage markers. Simultaneous display, on the other hand, made the events to be narrated available at all times. The order of the pictures materialized a process whose beginning, middle and end were indicated by the experimenter. This condition should facilitate the conceptual elaboration process. The events in this case could be integrated into an overall spatiotemporal representation, and a thematic unit that took the final change of topic into account (if any) could be generated. This mode should also allow the narrator to account for breaks in the ordered sequences. In all speakers, then, simultaneous display should promote the establishment of links between events and favour their explicit marking, particularly causal links in ordered sequences.

\section{RESULTS}

\section{Overall results}

Some children did not use any of the markers studied here (11 children) in the middle part of the narration (F2-F7). This was the case in arbitrary sequence narrations when the pictures were presented one at a time. In this production situation, nearly half the 7-year-olds ( 7 children out of 15) did not produce any markers, but all the 11-year-olds did. This observation provides an initial developmental indication of the 
joint importance of the display mode and the type of event sequence for link marking at the text level, with arbitrary sequences of events discovered one after another being the most unfavourable condition for younger participants.

For the other 180 children, the ratio of the type of semantic link they explicitly expressed during the narration of the events in frames F2-F7 was examined using an analysis of variance with ipsative measures (i.e., measures with four scores per participant, one for each type of semantic link) in such a way that each participant's total was equal to $100 \%$ (Greer \& Dunlap, 1997). The analysis design was 3 (Age: $7,9,11)_{-} 2$ (Display mode: simultaneous, consecutive)_ 2 (Type of event sequence: arbitrary, ordered) 4 (Semantic link: temporal, additive, adversative, causal) with repeated measures on the last factor. The analysis yielded a significant effect of semantic link $(F(3,507)=693.62, p<0.00001)$, which showed the following hierarchy. In first place came markers expressing a link of temporal succession (74.89\%), followed by markers expressing an additive link (17.62\%), and last were markers expressing a causal link (5.24\%) and markers expressing an adversative link (2.25\%). A pairwise comparison using the NewmanKeuls test (at a $p$-level of 0.01) showed that all but one difference between pairs were significant; the difference between the ratio of adversative and causal markers was nonsignificant. The analysis also showed a significant effect of the interaction between semantic link and display mode $(F(3,507)=12.82$, $p<0.00001)$, and between semantic link, display mode and age $(F(6,507)=4.503, p<0.0002)$. Figure 2 shows the ratio's distribution as a function of Age, Type of event sequence and Display mode.

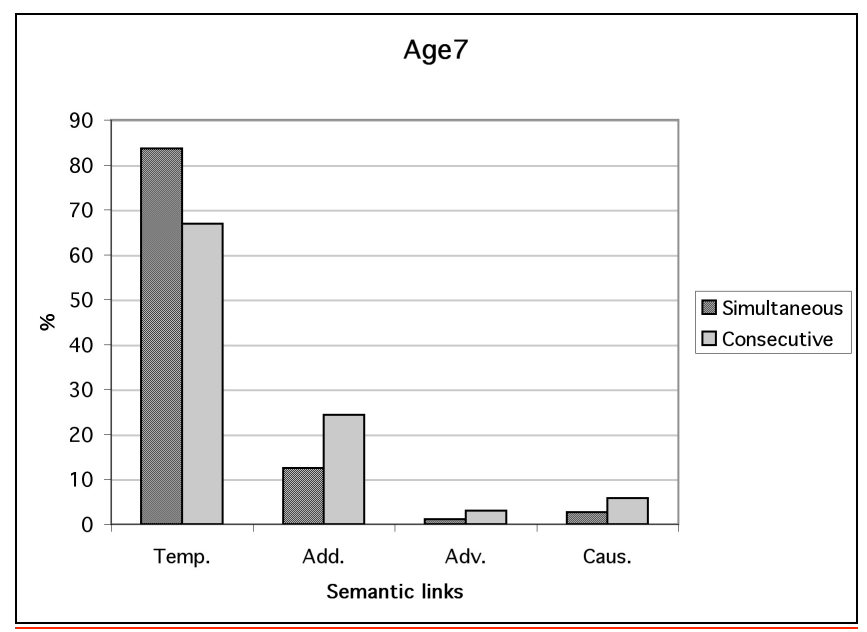



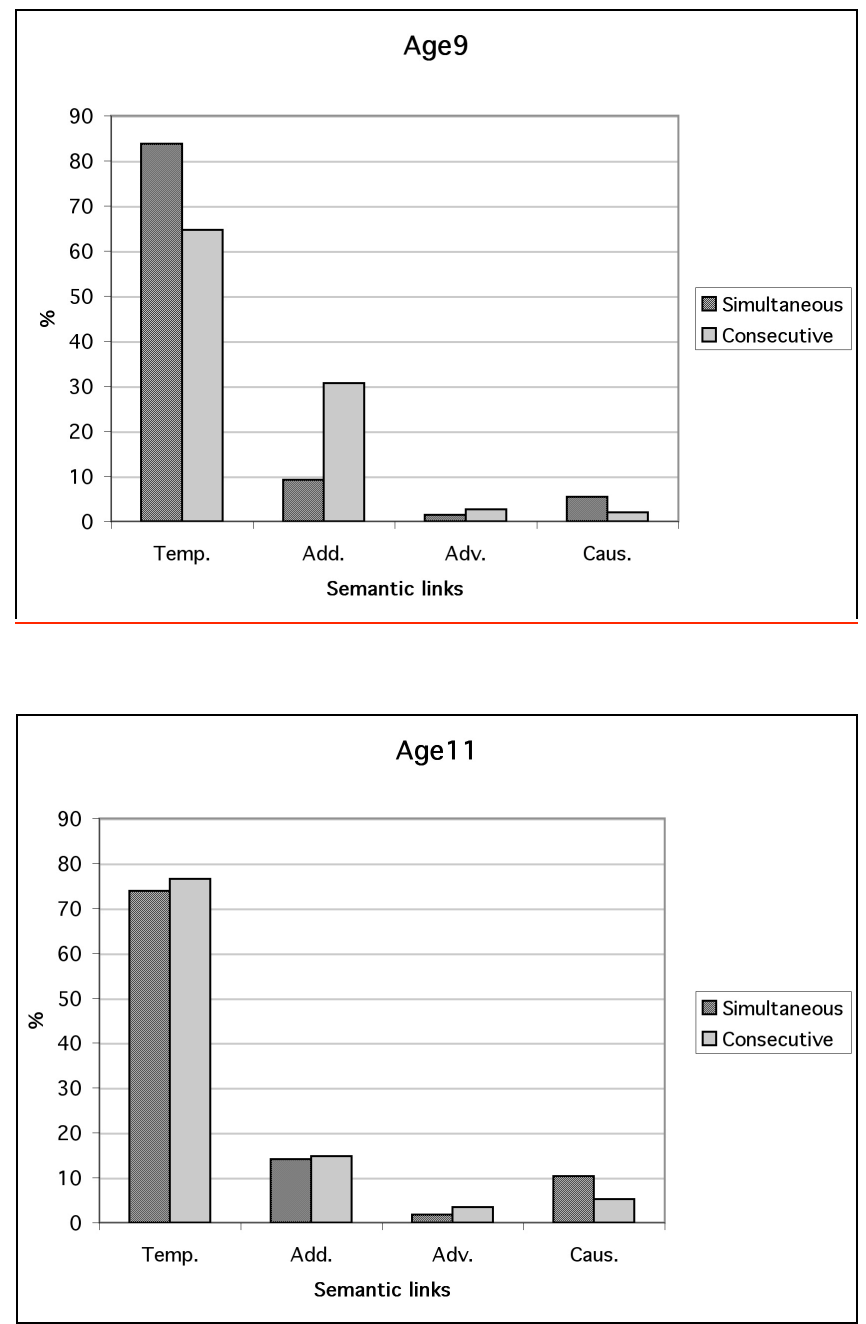

Figure 2 Percentage of markers occurrences, by semantic link, type of sequence and display mode: (a) age 7, (b) age 9 , (c) age 11

At ages 7 and 9, the distribution changed with the display mode, whereas this was no longer true at age 11. For both 7- and 9-year-olds, the ratio of temporal markers and additive markers varied across display modes: the ratio of temporal markers was greater in simultaneous than in consecutive display, whereas the ratio of additive markers was greater in consecutive display than in simultaneous display. This highlights the importance of the display mode in link marking in the youngest children.

\section{Detailed analyses}

To check the predictions about semantic link marking, the data were analysed separately for the arbitrary and ordered sequences. In each case, the effects of age and display mode were first tested using an analysis of variance with a 3 (Age: 7, 9, 11) _ 2 (Display mode: simultaneous, consecutive) design (hereafter denoted design 1). Moreover when the speakers discovered the pictures as they talked 
(consecutive display), they could not take the final change of topic (if any) into account so that marker use could only be analysed by age with a 3 (Age: 7, 9, 11) design (hereafter denoted design 2), whereas when the speakers saw the whole comic strip at once before narrating (simultaneous display) performance could be analysed by both age and thematic (dis)continuity with a 3 (Age: 7, 9, 11) _ 2 (Topic: maintained, changed) design with repeated measures on topic (hereafter denoted design 3). As dependent variables in the analyses, five 'density indexes' were calculated for each speaker. An overall density index was calculated by taking the ratio of the total number of markers to the total number of words produced, and similarly four separate density indexes were calculated, one for each type of link expressed (temporal, additive, adversative and causal). In the presentation below, only analyses yielding effects that were significant at 0.05 or less are mentioned and their results discussed.

\section{Arbitrary sequences}

For the arbitrary sequences, the analysis (design 1) with the overall density as dependant variable yielded a display-mode effect $(F(1,89)=10.71, p<0.001)$. As expected, overall marker density was greater in simultaneous than consecutive display mode $(\mathrm{S}=0.09$ vs. $\mathrm{C}=0.06)$.

Recall that when the pictures were discovered one at a time (consecutive display), barely half of the 7-year-olds used connectives. For these children, the most common marker was 'after that' (Example 6).

6. F2-F7: après maman elle va elle balaye ... après maman elle fait la cuisine ... a après elle frotte ... après elle se maquille ou elle se nettoie la figure ... après elle regarde la télé ... après elle tape à la machine ...

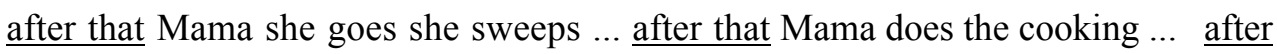
$\underline{\text { that }}$ she scrubs ... after that she puts on makeup or she cleans her face ... she watches TV ... after that she types on the typewriter ...

A total lack of connectives was less frequent in 9-year-olds (4 children out of 16). At this age, the first and second most frequent forms were après (after that) ensuite and (next), respectively. At age 11, all children used connectives, although some employed only temporal ones. The most common connectives at this age too were après and ensuite.

For the speakers who were asked in advance to try to understand the picture sequence as a story (simultaneous display) and who could thus grasp a topic change at the end of the comic strip (if it occurred), an analysis (design 3) with the overall density as dependant variable yielded an interaction effect between age and topic $(F(2,45)=4.47, p<0.017)$; see Fig. 3 . 


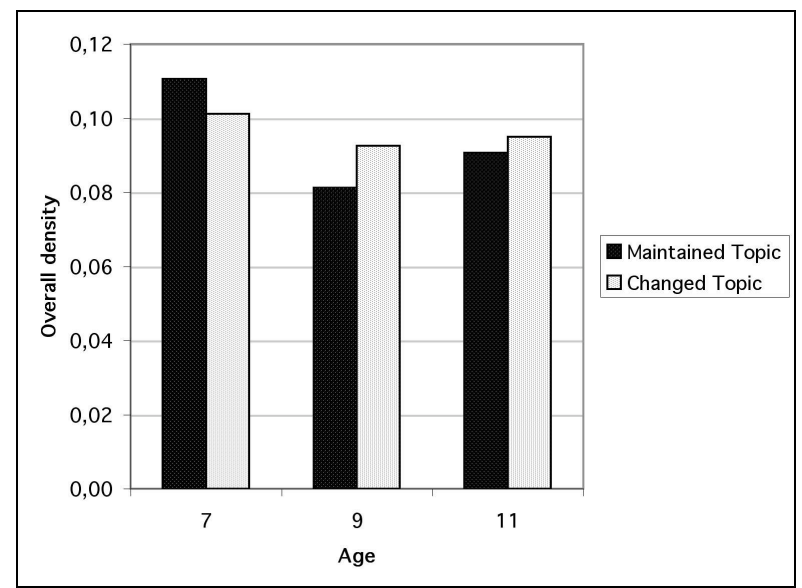

Figure 3 Arbitrary sequences: Age-by-Topic interaction in simultaneous display (overall markers density)

For the 7-year-olds, the overall marker density was at a peak when the topic was maintained until the end (F8), whereas the density was at its lowest in this case for the 9-year-olds. The performance of the 11year-olds varied little with the topic, and gave rise to a differentiated and opposing profile to that of the other two age groups.

To understand the above results in greater detail, the effects of the manipulated variables were examined separately for each type of semantic link (additive, temporal, causal, adversative). Analyses were first conducted with design 1 and then separately for each display mode (designs 2 and 3). Only the analyses with temporal marker density as the dependent variable yielded significant effects. These markers were denser in simultaneous than in consecutive display mode (design $1: \mathrm{S}=0.07$ vs. $\mathrm{C}=0.05$; $F(1,89)=9.92, p<0.002)$.

For speakers who saw all frames at once (simultaneous display mode), an analysis (design 3) yielded an interaction effect between age and topic $(F(2,45)=4.25, p<0.02)$; see Fig. 4 .

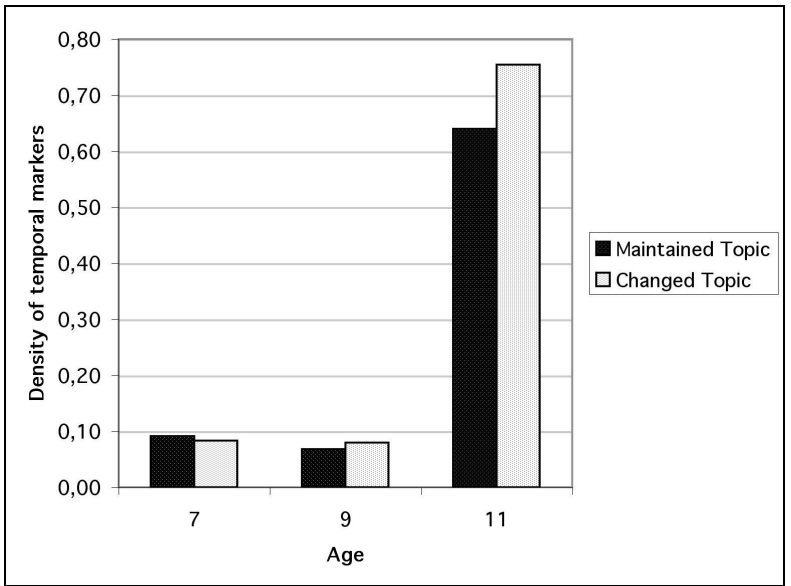

Figure 4 Arbitrary sequences: Age-by-Topic interaction in simultaneous display (density of temporal markers) 
The 7-year-olds used temporal markers in opposite manner to that of the 9- and 11-year-olds. At age 7, temporal marker density was higher than at age 9 or 11 when the topic was maintained and lower when the topic changed, whereas at 9 and 11 the reverse was found: lower density with a maintained topic and higher density with a changed topic. As illustrated in Example 7, when there was topic continuity, the youngest children used temporal markers (often in a redundant way) to introduce the events being related.

7. F2--F7: après la maman elle en a marre alors elle va faire le ménage. et après elle va faire la cuisine. et après elle se déshabille pour aller au marché. et après elle se met toute belle. et avant d'aller au marché elle regarde un peu les skieurs. et après elle fait qu'est-ce qu'elle va acheter sur une machine à écrire.

after that the Mom is fed up so she does the housework. and after that she cooks. and after that she gets undressed to go shopping. and after that she makes herself look pretty. and before going shopping she watches some skiers for awhile. and after that she writes down what she's going to buy on a typewriter.

For the other ages, however, the telling order itself usually served as an implicit indicator of the chronology of the events (the second event came after the first, and so on), as shown in Example 8.

8. F2-F7: alors, la fille elle fait le ménage ... elle fait à manger ... elle enfile sa robe ... elle se maquille ... elle regarde la télé ... ensuite elle frappe à la machine ...

F8: $\quad$ et elle s'en va faire les courses.

F2-F7: so the girl does the housework ... she makes the food ... she puts on her dress ... she puts on makeup ... she watches TV ... next she types on the typewriter ...

F8: $\quad$ and she leaves to go shopping.

On the other hand, these same children tended to mark temporal links when the last event in the series did not involve the same character (topic change), as in Example 9.

9. F2-F7: puis après elle nettoie la chambre ... puis ensuite elle va faire la cuisine ... après elle se déshabille ... après elle prépare, se maquille ... ensuite s'allonge, regarde la télé ... et puis après elle va taper à la machine...

F8: $\quad$ et ya son fiancé qui arrose le jardin.

F2-F7: then after that she cleans the bedroom ... then next she does the cooking ... after $\underline{\text { that }}$ she gets undressed ... $\underline{\text { after that }}$ she gets ready, puts on makeup ... next she lies down, watches TV ... and then after that she goes to type on the typewriter ... 
F8: $\quad$ and there's her boyfriend who's watering the garden.

In sum, in narrations of comic strips depicting a sequence of independent actions, most markers produced, as expected, expressed the temporal succession of the events, with 'after that' being the most prevalent form. Also, of line graphs of line graphs as expected, the use of markers in general, and temporal markers in particular, was more abundant when the speakers saw all pictures at once. In this case, the 7year-olds differed from the 9- and 11-year-olds as to when they did temporal marking: the youngest children did so when the same character was in every frame until the end (topic maintained), whereas the older ones did so mainly when there was a change of character in the last frame.

\section{Ordered sequences}

For the ordered sequences, the analysis (design 1) with the overall density as the dependent variable yielded a display mode effect $(F(1,90)=9.83, p<0.002)$ and an age effect $(F(2,90)=4.24, p<0.02)$ as expected. Concerning the display mode, as above for arbitrary sequences, the overall density was higher in simultaneous than consecutive display mode $(\mathrm{S}=0.09$ vs. $\mathrm{C}=0.06)$. Concerning age $(7 \mathrm{yrs}=0.06 ; 9 \mathrm{yrs}=$ $0.08 ; 11 \mathrm{yrs}=0.09$ ), pairwise comparisons using the Newman-Keuls test showed (at 0.05) that overall density was higher at age 11 than at age 7. A separate analysis for each display mode (designs 2 and 3) showed that this age effect only concerned speakers who discovered the pictures as they told the story (design 2: $7 \mathrm{yrs}=0.05,9 \mathrm{yrs}=0.06,11 \mathrm{yrs}=0.08 ; F(2,45)=4.39, p<0.02)$.

To go further into these findings, the effects of the manipulated variables were examined separately for each semantic link (additive, temporal, causal, adversative). The analysis (design 1) with the density of temporal markers as the dependent variable yielded a display mode effect analogous to that found for the entire set of markers, i.e., higher density in simultaneous display where speakers saw the whole comic strip before telling the story $(\mathrm{S}=0.05$ vs. $\mathrm{C}=0.07 ; F(1,90)=11.33, p<0.0011)$. The forms chosen usually varied within the same production (Example 10), with the two most prevalent ones being 'and' and 'after that'.

10. F3-F7: et le monsieur .... il lance sa canne à pêche ... ensuite elle part en arrière ... et puis ensuite il attrape un oiseau ... êt l'oiseau il le prend, après avec sa canne à pêche ... et après il le met dans ses mains.

and the man .... he throws out his fishing rod ... next it flies up behind him ... and then next he catches a bird ... and he takes the bird, after that with his fishing rod ... and after that he holds it in his hands. 
Looking separately at the density of the main temporal markers ('and' and 'after that'), we can see that these two forms complemented each other, both as a function of age and of display mode (design 1). The density pattern of 'after that' was similar to the overall trend, i.e., higher in simultaneous than in consecutive display ( $\mathrm{S}=0.02$ vs. $\mathrm{C}=0.01 ; F(1,90)=6.92, p<0.01)$. Although nonsignificant at the level set for this study, one overall tendency is worth mentioning: the density of 'after that' tended to decrease with age, especially in simultaneous display where it was the highest. The density of 'and' varied with the display mode: unlike 'after that', the density of 'and' was lower in simultaneous display than in consecutive display mode $(\mathrm{S}=0.009$ vs. $\mathrm{C}=0.013 ; F(1,90)=4.0, p<0.05)$, with age $(7 \mathrm{yrs}=0.007,9 \mathrm{yrs}$ $=0.014,11 \mathrm{yrs}=0.013 ; F(2,90)=8.39, p<0.0005)$ and produced an interaction between age and display mode $(F(2,90)=3.96, p<0.02)$; see Fig. 5 .

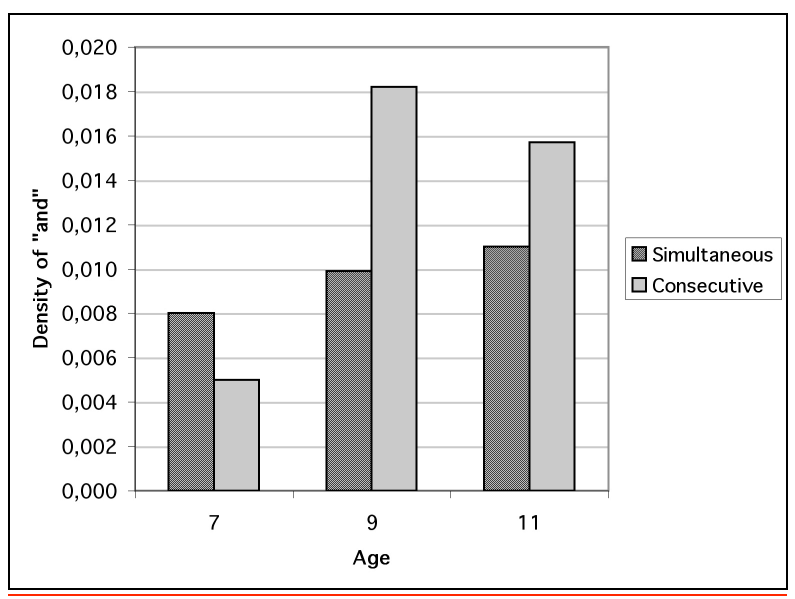

Figure 5 Ordered sequences: Age-by-Display mode interaction (density of 'and' as temporal marker)

For the 7-year-olds, the density of 'and' was higher in simultaneous than in consecutive display mode, whereas for the 9- and 11-year-olds the density of 'and' was higher in consecutive than in simultaneous display mode.

The analysis (design 1) of the density of additive markers yielded an age effect $(7 \mathrm{yrs}=0.007,9 \mathrm{yrs}=$ $0.015,11 \mathrm{yrs}=0.014 ; F(2,90)=9.34, p<0.0002)$. A pairwise comparison using the Newman-Keuls test showed (at 0.05) that additive connective density was lower for the 7-year-olds than for the 9- and 11year-olds (whose index was twice as high). A separate analysis for each display mode (designs 2 and 3) showed that the age effect only occurred for speakers who discovered the pictures as they talked (design 2: $7 \mathrm{yrs}=0.005,9 \mathrm{yrs}=0.018,11 \mathrm{yrs}=0.016 ; F(2,45)=10.36, p<0.0002)$. As an additive marker, 'and' was mainly used within utterances. It seems to be the means by which the 9- and 11-year-olds 'filled out' their narration in these cognitively constraining conditions for narrative organization (Example 11). 
11. F5: puis ensuite i s'retrouve avec la canne à pêche toute tordue à l'envers, et puis le fil qui est droit, très droit, vers l'arrière, et fait les yeux ronds et $i$ s'demande c'qui s'passe.

then next he ends up with the fishing rod all bent backwards, and then the wire that's straight, very straight, backwards, and opens his eyes wide and he wonders what's happening.

The analysis of the density of adversative markers (design 1) yielded an age effect $(7 \mathrm{yrs}=0.001,9 \mathrm{yrs}=$ $0.003,11 \mathrm{yrs}=0.004 ; F(2,90)=3.41, p<0.05)$. A pairwise comparison using the Newman-Keuls test showed (at 0.05) that adversative connective density, as expected, was higher for 11-year-olds than for 7year-olds. It seems that the contrast, marked by 'but' or 'but actually', was linked to the children's narrative development, and was therefore only expressed when there was a picture showing an unexpected element (Example 12).

12. F2-F7: le papa va à côté de l'étang ... il lance l'hameçon ... il essaye de lancer très loin ... mais sans le faire exprès il l'accroche, à un oiseau ... ensuite il tire et l'oiseau part avec.

the dad goes by the pond ... he throws out the bait ... he tries to throw it very far ... but without doing it on purpose he hooks a bird ... next he pulls and the bird comes with it.

The analysis of the density of causal markers (design 1) indicated effects of age $(7 \mathrm{yrs}=0.0007,9 \mathrm{yrs}=$ $0.003,11 \mathrm{yrs}=0.007 ; F(2,90)=12.51, p<0.00001)$ and display mode $(\mathrm{S}=0.006$ vs. $\mathrm{C}=0.002$; $F(1,90)=14.61, p<0.0002)$ and an interaction effect between the two $(F(2,90)=5.04, p<0.009)$; see Fig. 6.

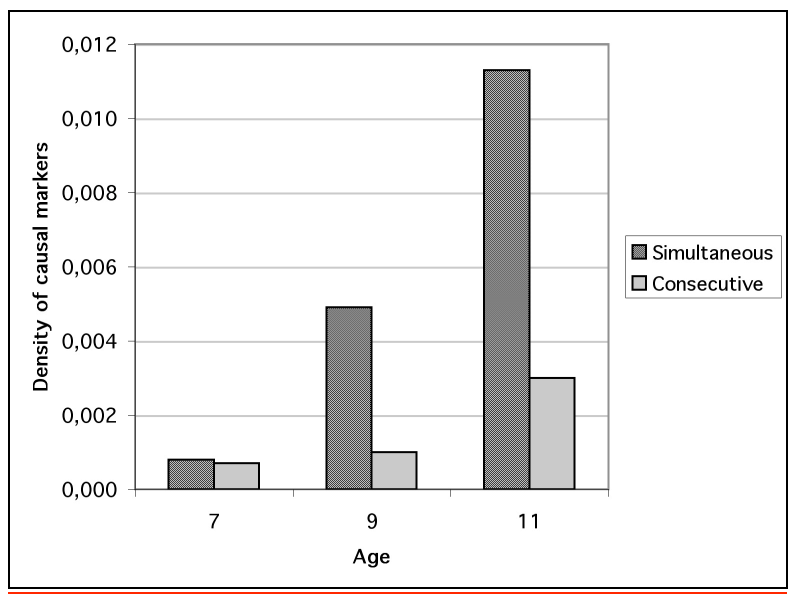

Figure 6 Ordered sequences: Age-by-Display mode interaction (density of causal markers) 
Causal connectives were used in the children's productions to express a cause-effect or consequence relation, marked by the connective 'so' (alors). In the display mode data, the causal connective density was higher in simultaneous display than in consecutive display. In the age data, a pairwise comparison using the Newman-Keuls test showed (at 0.01 ) that overall causal connective density was greater at age 11 than at 7 or 9 . As expected, this age effect was more pronounced when the speakers saw the whole comic strip before starting. The analysis of speakers who discovered the pictures as they narrated (design 2) yielded an age effect analogous to the one obtained for all speakers $(7 \mathrm{yrs}=0.0007,9 \mathrm{yrs}=0.001,11 \mathrm{yrs}=$ $0.003) ; F(2,45)=4.593, p<0.02)$. For those speakers who saw all frames at the same time and could therefore anticipate a potential topic change, the analysis (design 3) yielded the same, only stronger, age effect as above $(7 \mathrm{yrs}=0.0008,9 \mathrm{yrs}=0.005,11 \mathrm{yrs}=0.011 ; F(2,45)=9.25, p<0.0004)$. There was also an interaction effect between age and topic $(F(2,45)=3.53, p<0.05)$; see Fig. 7 .

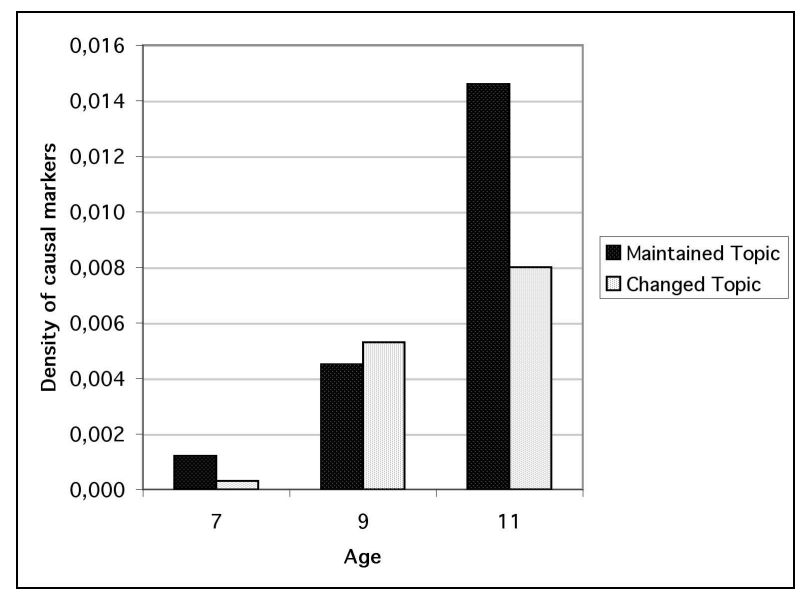

Figure 7 Ordered sequences: Age-by-Topic interaction (density of causal markers)

Only the 11-year-olds exhibited topic-related differences in the use of causal connectives. At this age, marker density was higher when the topic was maintained (Example 13) than when it changed, whereas a topic change did not affect the performance of the 7- and 9-year-olds.

13. F2-F7: après l'enfant il arrive devant la rivière ... $i$ s'assoit, et puis, $i$ pose le filet, et $i$ prend la canne à pêche. alors il attend, et à un moment, $i$ voit que ça mord, alors il est content, i tire, et puis c'était une chaussure qui était accrochée. alors il est déçu. et puis alors $i$ pose la chaussure et $i$ voit un poisson qui sort ... alors $i$ prend le filet, et il attrape le poisson.

after that the kid gets to the river ... he sits down, and then he puts the net down, and he takes the fishing rod. so he waits, and at one point, he sees that it's biting, so he's happy, he pulls, and then it's a shoe that's hooked on. so he's 
disappointed. and so then he puts the shoe down and he sees a fish coming out ... so he takes the net, and he catches the fish.

In sum, in narrations of comic strips showing a series of chronologically ordered events, more interpropositional links were expressed in general, and more temporal links in particular, when the speakers saw the whole comic strip at once, as expected. Compared with the younger children, the 11-year-olds diversified the range of markers used by expressing adversative and causal relations. The use of adversative markers, which appeared at a specific point in the narrations (when the obstacle came into the picture), did not depend on whether the speaker could organize the narration in advance, whereas causal relation marking (and temporal succession marking) did. In addition, the 9- and 11-year-olds differed from the younger children by their greater use of 'and' to mark additive and/or temporal relations when they saw the pictures one by one, a situation which created a memory load generated by the search for a link between the pictures.

\section{DISCUSSION}

The present experiment was devised to study how elementary schoolchildren used text organizers in picture-elicited oral narratives. The aim was to gain further insight into the impact of memory-searching constraints and inference-resolving constraints on the linguistic marking of inter-propositional links. The hypothesis was that the use of connectives depends not only upon the age-related improvement of children's ability to understand relationships between a series of events, but also upon what information is given in each frame and how that information is displayed. Only part of the children's narrations were in the scope of the present study, the part where they talked about pictures showing the same character carrying out a series of actions (F2-F7). Their use of connectives when narrating the event depicted in the last frame (F8) is reported elsewhere (Vion \& Colas, 2004).

In the data collection set-up devised for the study, few children constructed stories in which they assigned goals and motivations to the characters. The speakers usually focused on actions: as requested in the instructions, they faithfully reported the events shown in the pictures, only sometimes mentioning the characters' thoughts and affective reactions. As in previous research (for instance, for French oral narratives, see de Weck, 1991), a very high density of temporal text organizers was found (approximately 3 out of 4), along with the presence of combined markers (a connective plus another temporal marker such as 'and then', and 'when' and 'so now') at the beginning of propositions. As expected, the most conducive narration condition to the marking of inter-propositional links was the one in which all pictures were simultaneously available to the speakers.

The manipulation of the memory-searching and inference-resolving constraints allowed us to show, whatever the age of the participants, how temporal connectives were used (quantitatively and 
qualitatively). In the ordered sequence narrations, 2010 occurrences of an explicit marking of a temporal link of succession between propositions were found, and 2034 occurrences were found in the arbitrary sequence narrations. However, behind the quantitatively equivalent use of temporal markers in the two types of sequences, there was an important difference in the choosen markers.

In arbitrary sequence narration, links were mainly marked by 'after that' and 'next' (after that accounted for a little less than half of the temporal occurrences), whereas in ordered sequence narration, the link was marked first by 'and' (one third of the temporal occurrences) and second, by 'after that' (a little less than a third). Note also that combined markers were infrequent in the narrations of arbitrary sequences, whereas this type of marking was more common when the sequences were ordered.

In the literature, 'after that' and 'next' are considered to mark links between propositions belonging to the same textualization level. They situate an event in relation to other events within the same time period (the time during which the sequence of events unfolds; Bestgen \& Costermans, 1994). These two markers do not introduce refutation or a new topic, and they do not reinstate old topics (Jisa, 1984/85, 1987). Instead, they indicate the temporal succession of actions within a narrative. Like the connective 'then', they serve to mark a break in the event continuum and tend to be located at episode changes (Bestgen \& Vonk, 1995). The connective 'and' is seen as the trace of a 'relation-integration' process. It encodes the existence of inter-event continuity (Bestgen \& Costermans, 1994; Bestgen \& Vonk, 1995; McCabe \& Peterson, 1991; Segal, Duchan \& Scott, 1991) or more generally, continuity within a unit (Schiffrin, 1986, 1987).

The different temporal markers noted in this experiment showed that the choice of a form to express a link depends upon the intrinsic coherence of the material to be related. In arbitrary sequences where the simple narration order of the main character's actions was not enough to establish a coherent relation, coherence was achieved by means of markers indicating consecutiveness. When the narration order alone was sufficient to express the chronological link, each action was treated as an event that was part of a process. 'After that' tended to be less frequent in these productions, leaving room for forms that established a continuity link.

Furthermore, the manipulation of the memory-searching and inference-resolving constraints allowed us to assess the conduciveness of the different narration conditions to elicit each type of semantic link, as a function of age.

Concerning the arbitrary sequences, the only significant results obtained concerned the use of temporal markers. In consecutive displays, nearly half the 7-year-old children used no connectives at all. They did not connect the current event to the preceding one, no doubt because this display condition did not allow them to represent mentally the series of pictures as forming a whole. In contrast, simultaneous display triggered the substantial use of temporal markers by all 7-year-olds. Moreover, unlike the older children, the younger ones employed these markers more when the same character was present until the 
end of the comic strip. Thematic continuity thus seems to have helped the 7-year-olds relate the activities of a single character to each other via the systematic marking of the consecutiveness of events. The emerging sensitivity of 9-year-olds to the topic change also showed up in the simultaneous display mode. Noticing the change of character in the last picture, they, like the older children, explicitly marked the successive nature of the first character's actions. An explanation of the 9- and 11-year-olds' behaviour can be found in Schiffrin's (1987) linguistic analysis of the opposition between the presence of a marker (and) and the absence of a marker (zero). This author showed that 'and' and 'zero' can be used at the text level to make a syntagmatic contrast. Either one of these markers (irrespectively 'and' or 'zero') can be used to establish a text pattern that groups a series of propositions into a conceptual whole; the other, by virtue of the fact that it deviates from that pattern, marks a change in the organization of ideas. In the present experiment, thematic continuity helped the oldest children mark the temporal succession as they related the character's sequence of actions, usually by default (via the event narration order itself). This text pattern alone sufficed for grouping the sequence of coreferential utterances into a conceptual whole. The opposite text pattern seemed necessary when a topic change was expected at the end of the comic strip. In this case, the narrators relied on connectives like 'then', 'after that' and 'next' to mark the coreferential sequence.

Concerning the ordered sequences, significant results were obtained for all the semantic links they explicitly expressed. This type of material, which rendered the thread of the stories easier to grasp, made it possible to show that the 7-year-old children rarely marked adversative or causal relations, whereas the 11-year-olds did. Adversative relation marking did not vary with the frame display mode, and occurred solely when an obstacle was discovered. Unlike adversative relations, causal relation marking did depend upon the display mode. When the whole content of the comic strip was always available, the 11-year-olds marked causal relations more when the same character was involved until the end. Like the 7-year-olds for temporal succession marking, thematic continuity seems to have generated the optimal conditions for the search for and expression of causal links. When they were unaware of the content of the next picture, the 7-year-olds also differed from the 9- and 11-year-olds in their expression of additive or temporal links marked by 'and'. As far as additive links are concerned, the older children seem to have used them to make the most of the current picture while awaiting the discovery of the next event. As far as temporal links are concerned, the 9- and 11-year-olds relied more on 'and' when discovering and telling at the same time. Based on an analysis of the role of 'and' in oral exchanges, Schiffrin (1986) contended that this connective fulfils two simultaneous roles: one at the text-structuring level and one at the level of the speaker's acts. In the former case, 'and' serves as a discourse coordinator (it co-ordinates ideas within the text); in the latter, it announces that the utterance being produced is part of an unfinished interaction unit (i.e., it signals that the speaker has something else to say). In the present study, the oldest children (who used 'and' when discovering and talking at the same time) simultaneously marked both the link between 
propositions about the events being discovered, and the fact that the narration process was still underway. This production condition (ordered-consecutive), which provided a more 'tellable' support for the stories to be narrated but which required more effort in order to connect the pictures to each other, offered an excellent observation means for locating the point at which speakers switch from the descriptive mode to the narrative mode in their understanding of pictorial material.

To sum up, the pictorial-narrative verbalization task devised for this research, by the joint manipulation of the span of available information and the order of the events presented allowed us: (1) to determine the impact of the pictorial medium on the children's use of text organizers; (2) to show what leads oral narrators to mark inter-propositional links, and more specifically to employ a given form to express a temporal succession; and (3) to gain insight into the conditions under which the emerging narrative skills of children are manifested.

\section{ACKNOWLEDGEMENTS}

We would like to thank Delphine Baigue and Aïcha Idriss-Abdalla (graduate students) for their help in preparing the materials and collecting the data, and the superintendents, teachers and staff of the Chateau Double, Henri Wallon, Les Granettes, Luynes and St François d'Assise elementary schools in Aix-enProvence, France, for welcoming us in their classrooms.

\section{REFERENCES}

Adam, J. M. (1992). Les textes: types et prototypes. Paris: Nathan.

Bamberg, M. (1987). The acquisition of narratives. Learning to use language. Berlin: Mouton de Gruyter.

Bamberg, M. (1997). Narrative development: Six approaches. Mahwah, NJ: Erlbaum.

Berman, R. \& Katzenberg, I. (1998). Cognitive and linguistics factors in the development of picture-series narrations. In M. Chini \& A. Giacalone-Ramat (Eds), Studi italiani di linguistica teorica ed applicata, 27(1), 21-24 (special issue, ed. By Chini \& Giacalone-Ramat).

Berman, R. \& Slobin, D. (Eds) (1994). Different ways of relating events in narrative: A cross-linguistic developmental study. Hillsdale, NJ: Erlbaum.

Bestgen, Y. (1992). Structure cognitive et marquage linguistique de la narration: étude développementale. Archives de Psychologie, 60, 25-44.

Bestgen , Y. \& Costermans, J. (1994). Time, space, and action: Exploring the narrative structure and its linguistic marking. Discourse Processes, 17, 421-446.

Bestgen, Y. \& Vonk, W. (1995). The role of temporal segmentation markers in discourse processing. Discourse Processes, 19, 385-406.

Bloom, L., Lahey, M., Hood, L., Lifter, K. \& Fiess, K. (1980). Complex sentences: Acquisition of syntactic connectives and the semantic relations they encode. Journal of Child Language, 7, 235-261. 
Bock, K. (1995). Sentence production; from mind to mouth. In J. L. Miller \& P. D. Eimas (Eds), Speech language and communication (pp. 181-216). London: Academic Press.

Botvin, G. \& Sutton-Smith, B. (1977). The development of structural complexity in children's fantasy narratives. Developmental Psychology, 13, 377-378.

Bronckart, J. P. (1985). Pour un modèle de production du discours. In J. P. Bronckart (Ed.), Le fonctionnement des discours (pp. 3-58). Neuchâtel: Delachaux et Niestlé.

Bronckart, J. P. (1996). Activité langagière, textes et discours. Lausanne: Delachaux \& Niestlé.

Canoz, F. \& Vion, M. (1994). Encoding and maintaining reference in oral discourse. International Journal of Psychology, 29 (5), 537-564.

Chafe, W. (1986). Cognitive constraints on information flow. In R. Tomlin (Ed.), Coherence and grouping in discourse. Typological studies in language. Vol. 11 (pp. 21-51). Amsterdam: John Benjamins.

Danset-Léger, J. (1978). Pour une étude psychologique de la lecture des histoires en image par l'enfant. Journal de Psychologie, 3, 279-307.

De Weck, G. (1991). La cohésion dans les textes d'enfants: étude du développement des processus anaphoriques. Neuchâtel: Delachaux et Niestlé.

Deutsch, F. (1975). The effects of sex of subject and story character on preschoolers' perceptions of affective responses and intrapersonal behavior in story sequences. Developmental Psychology, 11, $112-113$.

Favart, M. (1997). Evolution de la planification écrite dans trois types de textes: analyse sur la base de la gestion de la cohésion (Ch. IV: Les connecteurs). Poitiers: Université de Poitiers (Thesis).

Fayol, M. (1986). Les connecteurs dans les récits écrits. Etude chez l'enfant de 6 à 10 ans. Pratiques, 49, 101-113.

Fayol, M. (1997). Des idées au texte, psychologie cognitive de la production verbale (pp. 145-177). Paris: Presses Universitaires de France.

Fine, J. (1985). Cohesion as an index of social cognitive factors: Oral language of the reading disabled. Discourse Processes, 1, 247-266.

Greer, T. \& Dunlap, W. P. (1997). Analysis of variance with ipsative measures. Psychological Methods, 2, 2, 200-207.

Hausendorf, H. (1993). L'adulte auditeur: aspects de l'étayage dans l'interaction avec des narrateurs enfants. Acquisition et Interaction en Langue Etrangère, 2, 85-105.

Hausendorf, H. \& Quasthoff, U. (1992). Patterns of adult-child interaction as a mechanism of discourse acquisition. Journal of Pragmatics, 17, 241-259.

Hemphill, L., Picardi, N. \& Tager-Flusberg, H. (1991). Narrative as an index of communicative competence in mildly mentally retarded children. Applied Psycholinguistics, 12, 263-279. 
Hickmann, M., Hendriks, H., Roland, F. \& Liang, J. (1994). The development of reference to person, time and space in discourse: A coding manual. Nijmegen: Max Planck Institute for Psycholinguistics.

Jisa, H. (1984/85). French preschoolers' use of 'et pis' ('and then'). First Language, 5, 169-184.

Jisa, H. (1987). Sentence connectors in French children's monologue performance. Journal of Pragmatics, $11,607-621$.

Jisa, H. (2000). Increasing cohesion in narratives: A developmental study of maintaining and reintroducing subjects in French. Linguistics, 38, 591-620.

Jisa, H. \& Kern, S. (1998). Relative clauses in French children's narrative text. Journal of Child Language, 25, 623-652.

Karmiloff-Smith, A. (1981). The grammatical marking of thematic structure in the development of language production. In W. Deutsch (Ed.), The child's construction of language (pp. 121-147). London: Academic Press.

Kern, S. (1998). Comment les enfants jonglent avec les contraites communicationnelles, discursives et linguistiques dans la production d'une narration. Lille: Presses Universitaires du Septentrion 2.

Levelt, J. M. (1989). Speaking. From intention to articulation. London: MIT Press.

MacWhinney, B. (1991). The Childes Project. Tool for analyzing talk. Hillsdale, NJ: Erlbaum.

McCabe, A. \& Peterson, C. (1991). Linking children's connective use and narrative macrostructure. In A. McCabe \& C. Peterson (Eds) Developing narrative structure (pp. 29-53). Hillsdale, NJ: Erlbaum.

McGann, W. \& Schwartz, A. (1988). Main character in children's narratives. Linguistics, 26, 215-233.

Mouchon, S., Fayol, M. \& Gombert, J. E. (1991). L'emploi de quelques connecteurs dans les récits: une tentative de comparaison oral/écrit chez des enfants de 5 à 11 ans. Repères, 3, 87-98.

Norris, J. A. \& Bruning, R. H. (1988). Cohesion in the narratives of good and poor readers. Journal of Speech and Hearing Disorders, 53, 416-424.

Peterson, C. (1993). Identifying referents and linking sentences cohesively in narration. Discourse Processes, 16, 507-524.

Peterson, C. \& McCabe, A. (1983). Developmental psycholinguistics: Three ways of looking at a child's narrative. New York: Plenum.

Rossari, C. (2000). Connecteurs et relations de discours: des liens entre cognition et signification. Nancy: Presses Universitaires de Nancy.

Roth, F. P. \& Spekman, N. J. (1989). Narratives discourse proficiency of learning disabled students: Differences between elicitation procedures. Symposium for Research on Child Language Disorders, Madison, WI.

Roth, F. P., Spekman, N. J. \& Fye, E. C. (1995). Reference cohesion in the oral narratives of students with learning disabilities and normally achieving students. Learning Disability Quarterly, 18, 25-39.

Schiffrin, D. (1986). Functions of and in discourse. Journal of Pragmatics, 10, 41-66. 
Schiffrin, D. (1987). Discourse markers. Cambridge: Cambridge University Press.

Schwartz, D. (1995). Reasoning about the referent of a picture versus reasoning about the picture as the referent: An effect of visual realism. Memory and Cognition, 23, 709-722.

Segal, E., Duchan, J. \& Scott, P. (1991). Role of interclausal connectives in narrative structuring: Evidence from adults' interpretations of simple stories. Discourse Processes, 14, 27-54.

Stein, N. \& Albro, E. (1997). Building complexity and coherence: Children's use of goal-structured knowledge in telling stories. In M. Bamberg (Ed.), Narrative development: Six approaches (pp. 5-44). Mahwah, NJ: Erlbaum.

Trabasso, T. \& Stein, N. (1997). Narrating, representing and remembering event sequences. In P. van den Broek, P. Bauer \& T. Bourg (Eds), Developmental spans in event comprehension and representation. Bridging fictional and actual events (pp. 237-270). Mahwah, NJ: Erlbaum.

van den Broek, P. (1997). Discovering the cement of the universe: the development of event comprehension from childhood to adulthood. In P. van den Broek, P. Bauer \& T. Bourg (Eds), Developmental spans in event comprehension and representation, bridging fictional and actual events (pp. 321-342). Mahwah, NJ: Erlbaum.

van den Broek, P., Bauer, P. \& Bourg, T. (1997). Developmental spans in event comprehension and representation, bridging fictional and actual events. Mahwah, NJ: Erlbaum.

Vion, M. \& Colas A. (1998). L’introduction des référents dans le discours en français: contraintes cognitives et développement des compétences narratives. L'Année Psychologique, 98, 37-59.

Vion, M. \& Colas, A. (1999a). Maintaining and reintroducing referents in French: cognitive constraints and development of narrative skills. Journal of Experimental Child Psychology, 72, 32-50.

Vion, M. \& Colas, A. (1999b). Expressing coreference in French: Cognitive constraints and development of narrative skills. Journal of Psycholinguistic Research, 28 (3), 261-291.

Vion, M. \& Colas, A. (2004). On the use of the connective 'and' in oral French narration: A study of French-speaking elementary school children. Journal of Child Language, 31, 399-419 . 


\section{APPENDIX}

\section{Experimental materials}

\section{Arbitrary sequences}

Test comic strips: content of first frame

1. A man and a woman sitting on a sofa

2. An adolescent and a little boy

3. A man and an adolescent at the beach

4. A woman and a little girl sitting at the table

5. A tortoise and a crocodile at the water's edge

6. A monkey and a lion in the brush

7. A hen and chicks in the courtyard

8. A cat and a donkey in the fields

Topic of filler comic strips (one character only)
a. A cat is playing by the sea
b. A grandmother is shopping
c. A man is getting up in the morning

\section{Ordered sequences}

Test comic strips: content of first frame

1. A child and an old man in the living room

2. A man and a woman at home

3. A boy and a girl at the beach

4. A boy and a man fishing

5. A dog and a cat sleeping on a rug

6. An earthworm and a snail in a kitchen

7. A hedgehog and a rabbit at the roadside

8. A fish and a frog near a pond

Topic of filler comic strips (one character only)
a. A dog is playing in a yard
b. A boy is exploring a cave
c. A mouse is looking for food 